\section{Incidental Medullary Thyroid Carcinoma in a Case of Graves' Disease}

Key words: ultrasonography, calcitonin, ret gene mutation

In 1999, Brandle et al reported two patients with Graves' disease who had concomitant medullary thyroid carcinoma (1). The presence of medullary thyroid carcinoma was suspected in one patient who exhibited diarrhea three months after treatment with carbimazole and was detected by ultrasonography $(2 \mathrm{~cm}$ in diameter). In the other patient, it was by Tc-99m pertechnetate scintigraphy (a $2-\mathrm{cm}$ cold nodule). Here, we report a patient with Graves' disease who had incidental medullary thyroid carcinoma.

A 32-year-old woman with Graves' disease was referred to our hospital for further treatment in May 1996. She was diagnosed as having Graves' hyperthyroidism in October 1994 and treatment with methimazole (MMI) was started. On physical examination, her thyroid gland was greatly enlarged and soft. Her blood pressure was $124 / 64 \mathrm{mmHg}$. Serum levels of free $\mathrm{T} 3$, free T4, and TSH were $2.4 \mathrm{pmol} / \mathrm{l}$ (normal 3.4-5.7), less than $1.3 \mathrm{pmol} / l$ (normal 10.8-23.3), and $99.7 \mathrm{mU} / \mathrm{l}$ (normal 0.43-4.09), respectively, when she was on $20 \mathrm{mg}$ /day of MMI. Her serum was positive for anti-TPO antibodies $(37 \mathrm{U} / \mathrm{ml}$, nor$\mathrm{mal}<0.3)$ and TSH-binding inhibitor immunoglobulins (54\%, normal $<15 \%$ ), but negative for thyroid-stimulating antibodies (TSAb) $(170 \%$, normal <180) and anti-thyroglobulin antibodies $(<0.3 \mathrm{U} / \mathrm{ml}$, normal $<0.3)$. Ultrasonic examination results using Aloka SSD-630 scanner with a 7.5-MHz ASU-32WL7.5 mechanical sector probe (Aloka Co., Tokyo) showed that

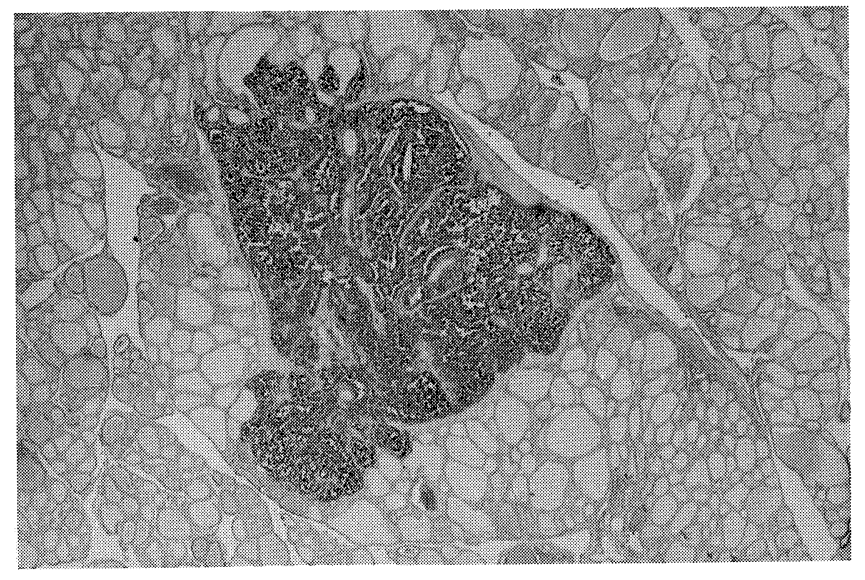

Figure 1. Calcitonin immunostaining in a section of the thyroid $(\times 20)$. The tumor cells are positive for calcitonin staining. her thyroid gland was diffusely enlarged and did not show the presence of any nodules. The MMI dose was decreased. Then, the size of her thyroid gland decreased. Subtotal thyroidectomy was performed in August 1996 since her family doctor suggested surgical treatment. Thirty-seven grams of her thyroid gland was resected and four grams remained. A small nodular lesion without a capsule $\left(3.5 \times 2.5 \mathrm{~mm}^{2}\right.$ in the section) was found in the right lobe of the resected thyroid gland. It showed solid and alveolar arrangement of small tumor cells. The cells showed fine granular cytoplasma and were immunohistochemically positive for calcitonin (Fig. 1) and carcinoembryonic antigen (CEA). Other surrounding thyroid tissue revealed diffuse hyperplasia. A diagnosis of Graves' disease concomitant with incidental medullary thyroid carcinoma was made. Serum calcitonin and CEA levels were $110 \mathrm{pg} / \mathrm{ml}($ normal <80) and 1.4 $\mathrm{ng} / \mathrm{ml}$ (normal $<2.5$ ), respectively, before the operation when frozen serum samples were used for the measurement. She became euthyroid or subclinical hypothyroid after the operation (TSH $3.47 \mathrm{mU} / \mathrm{l}$ in April 1997 and $4.54 \mathrm{mU} / \mathrm{l}$ in December 1998). The serum calcitonin level became normal after the operation (39 pg/ml in January 1997, less than $13 \mathrm{pg} / \mathrm{ml}$ in December 1998). Ret gene mutation was not demonstrated in exons 10 (codons 609, 611, 618, and 620), 11 (codon 634), or 16 (codon 918).

When a thyroid nodule is detected in patients with Graves' disease, the presence of thyroid carcinoma, particularly differentiated thyroid carcinoma, should be considered (2-4). TSAb are thought to play a role in promoting the growth of differentiated thyroid carcinomas having a TSH receptor on their surface $(2,5)$. In contrast, C-cells, the origin of medullary thyroid carcinoma cells, do not have a TSH receptor on their surface. However, it is not conclusive that the combination of medullary thyroid carcinoma and Graves' disease is coincidental since a few reports showed that the ratio of medullary thyroid carcinoma to papillary (or follicular) thyroid carcinoma found in patients with Graves' disease was unexpectedly high $(3,4)$. In our patient, the serum calcitonin level was high although the size of the tumor was very small, suggesting that measurement of the serum calcitonin level is a useful tool for diagnosing the presence of medullary thyroid carcinoma in patients with Graves' disease even when nodular lesion is not detected by ultrasonography or scintigraphy. In addition, the serum level of calcitonin was normal (25.6 \pm 7.1 (mean $\pm \mathrm{SD}) \mathrm{pg} / \mathrm{ml}$, range $13-40 \mathrm{pg} / \mathrm{ml}$ ) in 24 other patients with Graves' disease who visited our hospital in October 2001 before $(\mathrm{n}=7)$ and during $(n=17)$ treatment with an anti-thyroid drug.

\section{Shigenori NAKAmURA, Yukie SAIO, Masatoshi IsHIMORI and Hiroto SHIMA*}

From the Department of Internal Medicine and *the Department of Pathology, Gifu Red Cross Hospital, Gifu 
Received for publication September 4, 2001; Accepted for publication December 24, 2001

Reprint requests should be addressed to Dr. Shigenori Nakamura, the Department of Internal Medicine, Gifu Red Cross Hospital, 3-36 Iwakura, Gifu 5028511

\section{References}

1) Brandle M, Galeazzi RL, Diener P-A, Schmid C. Medullary thyroid carcinoma in Graves' disease. Clin Endocrinol (Oxf) 50: 545-546, 1999 (letter).
2) Belfiore $A$, Garofalo MR, Giuffrida $D$, et al. Increased aggressiveness of thyroid cancer in patients with Graves' disease. J Clin Endocrinol Metab 70: 830-835, 1990.

3) Diklic A, Paunovic I, Batev N, Malenkovic V, Havelka M, Jankovic R. Occurrence of thyroid gland carcinoma in Graves-Basedow disease. Acta Chir lugosl 38: 61-68. 1991.

4) Ardito G, Mantovani M, Vincenzoni C, et al. Hyperthyroidism and carcinoma of the thyroid gland. Ann Ital Chir 68: 23-27; discussion 27-28, 1997.

5) Filetti S, Belfiore A, Amir SM, et al. The role of thyroid stimulating antibodies of Graves' disease in differentiated thyroid cancer. N Engl J Med 318: 753-759, 1988. 